\title{
Dewey, Democracy and Education, and the School Curriculum
}

\section{Education 3-13 (Special Edition)}

\author{
Dr Neil Hopkins \\ School of Teacher Education \\ University of Bedfordshire, UK \\ neil.hopkins@beds.ac.uk
}

\begin{abstract}
This paper will investigate Dewey's Democracy and Education in relation to the curriculum. There are two overarching themes to the paper: the concept of the democratic curriculum and the academic/vocational divide. Dewey is seen as a pivotal thinker in relation to collaborative learning and the child as a vital voice in any learning that takes place in the classroom and beyond. The paper explores whether issues such as school governance and pupil voice facilitate Dewey's notion of democratic education. Alongside this is the issue of the academic/vocational divide within English education. Acknowledgement will be made of Dewey's theory of knowledge which emphasises the connection between concept and application and how this can influence the incorporation of the theoretical and the practical as part of children's learning in a given curriculum.
\end{abstract}

\section{Introduction}

Dewey's Democracy and Education is a landmark publication in education generally and philosophy of education in particular. Hence, the tributes and appraisals of the book as part of its centenary (includsing this special editaion of Education 3-13). My focus in this chapter will be on the relavancy of Democracy and Education to the contemporary curriculum. Does a book published over one hundred years ago still speak to educational practitioners, adminstrators and policy-makers? The curriculum in state education in the United Kingdom (as with many other countries) has been increasingly politicised over the past thirty or forty years. In the UK, the introduction of the National Curriculum in the late 1980s standardised (to a greater or lesser extent) what children were expected to learn and when they were expected to learn it. There have been various government strategies and policies since then (for 
example, the National Literacy and Numeracy Strategies in the late 1990s and the debate over synthetic phonics over the last decade or so). So how does Democracy and Education relate to this educational landscape?

I will be looking sepcifically at Dewey's interpretation of democratic education and how this can and does apply to current issues in English primary and secondary education. Does Dewey's ideas have any connection with the recent introduction of Fundamental British Values? What the the implications for pupil voice of Dewey's views of the child in Democracy and Education? Where do Dewey's thoughts resonate in an era of standards, deregulation and national benchmarks? I will be endeavouring to explore these questions alongside the other key element of this paper: the academic/vocational divide in English education. I argue that this division has been a key weakness of English education over many decades and Dewey offers important insights into how this weakness can be addressed. I will offer his theory of knowledge in Democracy and Education (in relaion to pedagogy) as a means to overcoming such divisions in the curriculum.

It is important to emphasise, as part of this chapter, how important democratic values and practices are for primary school practitioners (as well as their secondary counterparts). I hope to show here how the current educational landscape (especially the focus regarding 'Britishness' and PREVENT) relates clearly to the work and expectations for teachers in both primary and secondary schools. These issues remind us of Dewey's contemporary relevance in the area of democracy, citizenship and the curriculum for practitioners from the Early Years Foundation Stage to Key Stage 3.

\section{Democracy and the democratic curriculum}

It is important to state from the beginning that Dewey found the notion of statecontrolled education problematic. In this sense, he was close to liberal thinkers of the nineteenth century such as John Stuart Mill. Dewey states:

Is it possible for an educational system to be conducted by a national state and yet the full social ends of the educative process not to be restricted, constrained or corrupted? (Dewey 2007: 75).

Dewey was concerned that state control of education (and, by implication, the curriculum) could lead to situations where emphasis was placed upon the needs of 
the nation rather than the needs of the individual child. This is a particular concern in times of national strife and conflict where education is often viewed as a vehicle for social cohesion or improving national pride and performance. It could be argued, with the advent of the PREVENT agenda on radicalisation, the simmering issue of Scottish independence, and the tensions created by Brexit, the UK is currently encountering a climate of strife and conflict. Dewey was very aware of the tensions between democratic values and nationalist sentiment in relation to education. $\mathrm{He}$ argues in Democracy and Education: 'One of the fundamental [tensions] of education in and for a democratic society is set by the conflict of a nationalistic and wider social aim' (Dewey 2007: 75).

A key issue regarding the government, the curriculum and a sense of nationhood has been the introduction of 'Fundamental British Values' and the PREVENT duty for teachers in schools and colleges. Fundamental British Values (FBV) were introduced by the Department for Education in 2014 and comprise of 'democracy, the rule of law, individual liberty, and mutual respect and tolerance of those with different faiths and beliefs' (DfE 2014: 5). Schools are encouraged to integrate FBV as part of pupils' spiritual, moral, social and cultural (SMSC) development (as stipulated in the Education Act (2002)). On the surface, FBV could be seen as relatively benign - a statement of values that most 'reasonable' people would conform and adhere to as a means of working and living together within a multicultural society. However, the labelling of these values as 'British' has caused considerable debate (see, for instance, Elton-Chalcraft et al. 2017). There is little that is inherently 'British' regarding the values themselves and it is often taken as read what the concepts mean. Fundamental questions occur over whether the curriculum is a place to induct pupils into a sense of what it means to be British and the relative lack of consultation prior to formulating these particular values as being 'Fundamentally British'. For Dewey, there is an inherent tension between education-for-national identity and democratic education as a social activity and aim. He would be sceptical of government interpretations of democracy in an educational context.

Dewey had a very deep attachment to the concept of democracy and what this looked like within the classroom. Most people are familiar with Dewey's famous phrase of democracy being more than a form of government; it is primarily a form of associated living, of conjoint communicated experience' (Dewey 2007: 68)'. For Dewey, democracy and democratic education was an inherently collective affair. He 
states: 'In order to have a large number of values in common, all members of the group must have an equable opportunity to receive and take from others' (Dewey 2007: 66). What is interesting when comparing FBV and Dewey's views on democracy is the relative absence of collectivity and equality regarding FBV (although the reference to 'democracy' in FBV does hint at collective decision making). Dewey viewed the classroom as a place where people discovered and constructed knowledge together as relative equals (the teacher having a particular responsibility due to her/his role). Education, for Dewey, is a shared enterprise and this is what made him seem dangerous and radical to those educationalists and politicians who had a traditional view of the curriculum and the child's place within it. If democracy was to have any meaning beyond the dry practice of electoral procedures and the knockabout 'Punch and Judy' of parliamentary discourse, then it should occur as part of the educational process itself. Democracy is not something that happens (as if by magic) when a student turns into a citizen at eighteen. Children learn to work together, discuss and argue over common themes and problems encountered daily as part of their educational experiences. The teacher's role is critical but does not 'trump' the children's voices within the learning environment. In Experience and Education (1938) which was, to some extent, a follow-up to Democracy and Education, Dewey says:

it is not the will or desire of any one person which establishes order but the moving spirit of the whole group. The control is social, but individuals are part of a community, not outside of it ... the teacher exercises [authority] as a representative or agent of the interests of the group as a whole (Dewey 1950: 58-59).

The sense of collectivity and equality is clear in this passage. However, it also presents challenges for teachers, pupils and policy-makers. If, as Dewey indicated in Democracy and Education, there is a concern with state-controlled education, how can we also advocate education as social participation without that being a contradiction? Where do we draw the line between the classroom as a community and the 'national community' controlling the classroom? Is the classroom a 'sealed unit' where participation and discussion occur without inference from outside or is the classroom an essential part of the wider community? Dewey appears to suggest the latter:

An undesirable society ... is one which internally and externally sets up barriers to free intercourse and communication of experience. A society which makes provision for participation in its good of all its members on equal terms 
and which secures flexible readjustment of its institutions through interaction of the different forms of associated life is in so far democratic. Such a society must have a type of education which gives individuals a personal interest in social relationships and control, and the habits of mind which secure social changes without introducing disorder (Dewey 2007: 76).

As is evident, Dewey did not want to sacrifice the individual in pursuit of collective experiences in education. In that sense, his views match the emphasis on the individual liberty element of FBV. Much has been made in the past century of Dewey as an advocate of 'child-centred' education by both his supporters and critics. Dewey was very sensitive to such labels and how they could be misinterpreted. In Experience and Education, Dewey was critical of those educationalists who took the child-centred approach to mean they were absolved of curriculum planning or organization: 'Failure to develop a conception of organization upon the empirical and experimental basis gives reactionaries a too easy victory (Dewey 1950: 22). Although Dewey could see the dangers of taking such ideas too far, he believed in education as a means of facilitating and enhancing children's individual growth. He had a complex view of how such growth occurred, critiquing education as form of 'unfolding', 'preparation' or 'formation'. For Dewey,

The idea of education ... is formally summed up in the idea of continuous reconstruction of experience, an idea which is marked off from education as preparation for a remote future, as unfolding, as external formation, and as recapitulation of the past (Dewey 2007: 63).

Children's experiences were to form a critical aspect of a given curriculum. It is through experience that concept and context can work together to support and develop a child's understanding:

An experience, a very humble experience, is capable of generating and carrying any amount of theory (or intellectual context), but a theory apart from experience cannot be definitively grasped even as theory (Dewey 2007: 110).

Dewey provides here important criticisms of rote and didactic forms of pedagogy. Without children being able to make connections between ideas and their basis in a child's sense of reality, the ideas remain abstractions without meaning or applicability. These notions embody Dewey's philosophical pragmatism and have had important consequences regarding the curriculum and how children learn. After Democracy and Education, it became increasingly difficult for educationalists to argue for a curriculum where children were largely passive and seen as the 
recipients rather than participants in the construction of their knowledge.

\section{The Common School as a form of democratic education}

How might Dewey's views in Democracy and Education translate in practice? An interesting example is provided in Michael Fielding's paper, 'On the Necessity of Radical State Education: Democracy and the Common School' (2007). In this paper, Fielding takes the historical example of St. George-in-the-East Secondary Modern School in Stepney, East London in 1953. According to Fielding,

St.George-in-the East had the most sophisticated formal democratic structure I have ever encountered in a secondary school, with multiple, organically related democratic constituencies operating on a weekly and monthly basis in the three arenas of staff, students and school (Fielding 2007: 548-549).

Alongside this democratic decision-making structure were what Fielding terms as 'existential frameworks for democratic living' ('Our Pattern'). These include values and principles that underpin the work of the school. As part of 'Our Pattern', a farreaching set of beliefs and attitudes were formulated within the school body:

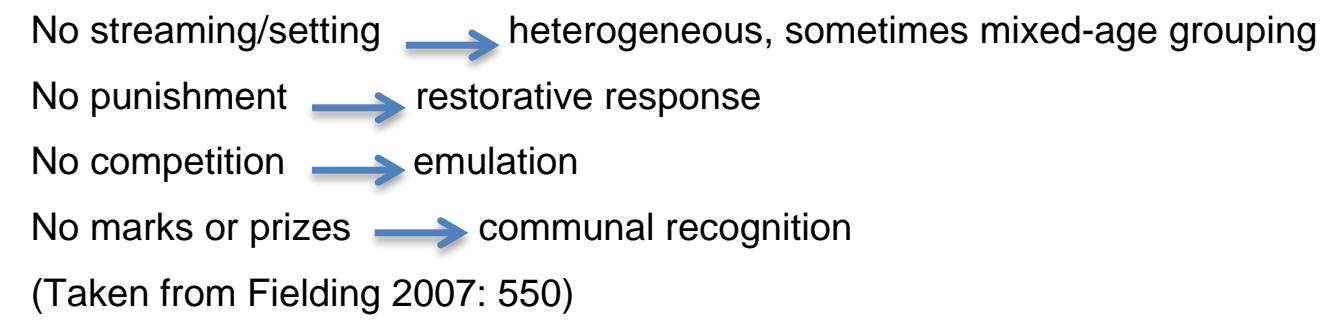

These values and principles at St.George-in-the-East supported what Fielding calls 'radical collegiality' in relation to the school curriculum. Fielding depicts this idea in the form of a table: 
- School study

- The community as a resource

- Electives

- Residential camps
- Animating dynamic of mutual learning between students and staff

- Weekly reviews

- Continuity of relationships

- Form meetings, pupil panels, pupil committees, joint panel and whole school council

(Taken from Fielding 2007: 550)

With regards to the 'emergent curriculum', Fielding takes each element in turn and described it in relation to his views on radical education:

(a) the School Study - school-wide thematic work interpreted differently by different groups and individuals within different classes but communally interrogated and appreciated in a variety of often mixed-aged settings; (b) widespread use of the community, of London, not just the local district as a learning resource; (c) daily electives in which the afternoon curriculum was chosen by the pupils themselves; and (d) residential camps in which intergenerational, exploratory learning was much in evidence (Fielding 2007: 551).

This portrayal of the curriculum is a refreshing antidote to the frequent concerns and complaints that the primary and secondary curriculums in England are too closely linked to measurements, standards and performance in relation to external bodies and indicators. There is a degree of curriculum choice and pupil autonomy that is difficult (but not impossible) to create in the current school environment. I personally found it very encouraging when staff and students from Hockerill Anglo-European College discussed (at the Democracy and Education centennial conference at Homerton College, Cambridge) how values and principles very similar to St.Georgein-the-East are integrated into their own curriculum as part of a conscious effort to encourage and facilitate democratic structures and beliefs within the school.

Certainly, St.George-in-the-East epitomized the Deweyan philosophy regarding the curriculum in its incorporation of the wider community as part of the learning environment and the importance of students' own interests and experiences as central elements of the learning process. 
What is particularly interesting in Fielding's portrayal of St.George-in-the-East as a 'common school' is how closely many of the processes are closely to what contemporary educators would term as 'pupil voice'. One of the criticisms of pupil voice in the contemporary school and classroom is how effective it is in genuinely allowing and encouraging children to participate in their own learning. The danger is that pupil voice becomes tokenistic or a 'tick box' to satisfy inspection regimes.

St.George-in-the East's emphasis is on a dialogical relationship between teachers and pupils, encapsulated in the phrase, 'Animating dynamic of mutual learning between students and staff' (Fielding 2007: 550). This prevents pupil voice lapsing into the tokenistic because the dynamic between teacher and students is ongoing and pervasive. As Robin Alexander has pointed out in relation to dialogic teaching in practice (from his work in schools in Yorkshire and Barking and Dagenham in 2001 and 2002):

- There is more talking about talk, by children as well as teachers

- Teachers and children are devising ground rules for the management of discussion

- Children are speculating, thinking aloud and helping each other, rather than competing to spot the 'right' answer

- There is greater involvement of less able children who are finding the changed dynamics of classroom talk provide them alternative opportunities to show competence and progress, and of those quiet, compliant children 'in the middle' who are often inhibited by unfocused questioning, the competitiveness of bidding and the dominance of some of their peers

- Student contributions are becoming more diverse. Instead of just factual recall there are now contributions of an expository, explanatory, justificatory or speculative kind

- There is more student-student talk

(Adapted from Alexander 2008: 115-117)

\section{Dewey and the academic/vocational divide in the curriculum}

A critical area where Dewey's Democracy and Education challenged contemporary assumption on the curriculum was the idea that children and knowledge could be categorized as 'academic' and 'vocational'. Such divisions have straitjacketed British education for the last 150 years both institutionally (eg. grammar and second modern schools; sixth-forms and FE colleges) and in terms of qualifications (eg. O 
Level/CSE; A Level/BTEC). These divisions have often replicated class divisions within society-at-large to the extent that schools have often been seen as the nurseries of inequality and social injustice.

Dewey attacked the academic/vocational divide in terms of both knowledge and education. As a philosophical pragmatist, he was skeptical of purely abstract knowledge, stating that "the separation of "mind" from direct occupation with things throws emphasis on things at the expense of relations or connections' (Dewey 2007: 109). These relations and connections are vital - once mind is separated from body, we lose the vital thread that ties ideas with standard notions of reality. Knowledge is an interaction of key concepts with the world as we know it. It is this sense of application and practicality that distinguishes Dewey's work from some of his contemporaries. He was critical of

intellectualism [where] [p]ractice was not so much so much subordinated to knowledge as treated as a kind of tag-end or aftermath of knowledge. The educational result was only to confirm the exclusion of active pursuits from school, save that they might be brought in for purely utilitarian ends - the acquisition by drill of certain habits (Dewey 2007: 197).

This separation of intellect and practice, mind and body is often_mirrored within the education system itself:

To these two modes of occupation, with their distinction of servile and free activities ... correspond two types of education: the base or mechanical and the liberal or intellectual' (Dewey 2007: 188).

To this extent, education replicates and prepares children for the division of labour that exists within a capitalist society. This state of affairs deeply concerned Dewey in two ways. Firstly, as I have alluded to above, the partition of learning into academic and vocational gives a false depiction of how knowledge is conceptualized and transmitted. Secondly, the use of academic and vocational routes for students does not allow each to develop their faculties to their fullest extent. In England, this divide was formalized with the creation of grammar schools and secondary moderns after the 1944 Education Act. The curriculum for each type of school was geared explicitly towards the function students were expected to play once they had left the education system. This, it could be argued, had the benefit of specialisation, allowing students to develop their perceived strengths in tandem with others of like minds and abilities. However, the downside of such specialization is the focus on certain areas of education and life at the exclusion of others at an early age. Dewey, in Experience 
and Education, states:

A fully integrated personality ... exists only when successive experiences are integrated with one another. It can be built up only as a world of related objects is constructed (Dewey 1950: 43).

Such integration cannot occur effectively when the curriculum is biased towards either the academic or the vocational. According to Dewey, the relation between people, concepts and objects is a holistic relationship - we lose something when we study any of them in isolation from others. Dewey was concerned that creating different 'pathways' or 'routes' for children was preventing them from viewing knowledge 'in the round' and this, in turn, would have a detrimental effect on their overall development as students and as human beings.

The move towards comprehensive schools in the 1960s and 1970s was an attempt to soften or eradicate these social and educational differences. Some educators saw opportunities to transfer comprehensives into Fielding's depiction of the Common School (2007) (as discussed in the section above). Whilst there were notable attempts $^{1}$ at common schools, the bipartite division in the secondary examination system (GCEs and CSEs) tended to replicate the academic/vocational divide found in grammar schools and secondary moderns - the difference being that the students were now studying within one institution. The movement towards GCSEs was an attempt to remove these barriers and ensure all children took one qualification at the end of compulsory schooling. However, even within the GCSE system itself there has been a tendency to draw distinctions that are not dissimilar to the GCE/CSE situation of the 1960s and 1970s in England. It could be argued that the focus on national and local benchmarks for GCSE $A^{*}-C^{2}$ and the introduction of the EBacc have created similar distinctions between students and subjects even within a system that is purportedly uniform.

The introduction of the National Curriculum in England in the late 1980s provided an entitlement for children (in terms of curriculum aims and programmes of study) across England. What has been a concern throughout the lifespan of the National Curriculum is the creation of 'core' and 'foundation' subjects with priority given to those 'core' subjects at the expense of other areas of study. Dewey argued,

\footnotetext{
${ }^{1}$ Michael Fielding offers Countesthorpe Community College, Leicestershire and Bishops Park College, Clacton as examples (Fielding 2007: 551).

${ }^{2}$ It will be interesting to see if this process remains as the GCSEs revert to a numerical grading system (9-1).
} 
The notions that the "essentials" of elementary education are the three Rs mechanically treated ... is based upon an ignorance of the essentials needed for realization of democratic ideals (Dewey 2007: 145).

No one would suggest that Dewey's depiction above is bourn out in contemporary primary and secondary classrooms in England. However, Dewey's point does carry a wider charge - there is a danger, when we focus on certain parts of the curriculum to the exclusion of others, that we jeopardise the social gains we could potentially make when education strives towards being more democratic. For Dewey, such an education contained elements of both the academic and the vocational.

\section{Does the 'creative curriculum' challenge this divide?}

Over the past ten or fifteen years, many primary and secondary schools have taken a more holistic, integrated or thematic approach to the curriculum. This has sometimes been described as a 'creative curriculum' although other terms have also been used. I am going to look briefly at one instance of such an approach. The school in question is Kingsholm Primary School in Gloucester. The school was the subject of a Teachers TV broadcast entitled 'Primary Topic Work - Customise Your Curriculum: Giant Leaps'.

Kingsholm Primary made a strategic decision to move from a subject-based to a thematic curriculum to meet the perceived needs of the pupils at the school. As can be seen in Figure 2 below, the curriculum has been envisaged as a set of interconnecting circles to incorporate aspects of the child's world, specific themes/curriculum areas, the geographical location and what the school has termed 'the wider curriculum'. One particular theme that was concentrated on in the video was 'Earth and Beyond'. This was a Year 5/6 project that uses the idea of space to explore different elements of the primary curriculum. The theme included transforming the learning environment itself (see Figure 1) alongside work on the creation of a space poem using 'word stones' and a collaborative dance interpreting the concept of space in the form of bodily movement (as well as other activities).

It has to be acknowledged that such examples already build upon the excellent work 
on themes and projects undertaken by schools throughout England. These examples offer interesting opportunities to challenge the academic/vocational divide in the school curriculum. It allows children to see and create the connections between different aspects of knowledge so that concepts and their application become concrete. As we have already seen, this dynamic between concept and application was important in Dewey's theory of knowledge. However, such innovations are likely to be easier to undertake in Early Years and Key Stage 1 - the requirements of programmes of study in Key Stage 2 and beyond make such thematic work more challenging (although not necessarily impossible), It will be interesting to see if the development of academies and free schools that can operate outside the parameters of the National Curriculum will lead to radical curriculum experiments in secondary schools. For Dewey, such curricular innovation needed to take this statement as a starting point:

In just the degree in which connections are established between what happens to a person and what he [sic] does in response, and between what he does to his [sic] environment and what it does in response to him, his acts and the things about him acquire meaning. He learns to understand both himself [sic] and the world of men [sic] and things (Dewey 2007: 202).

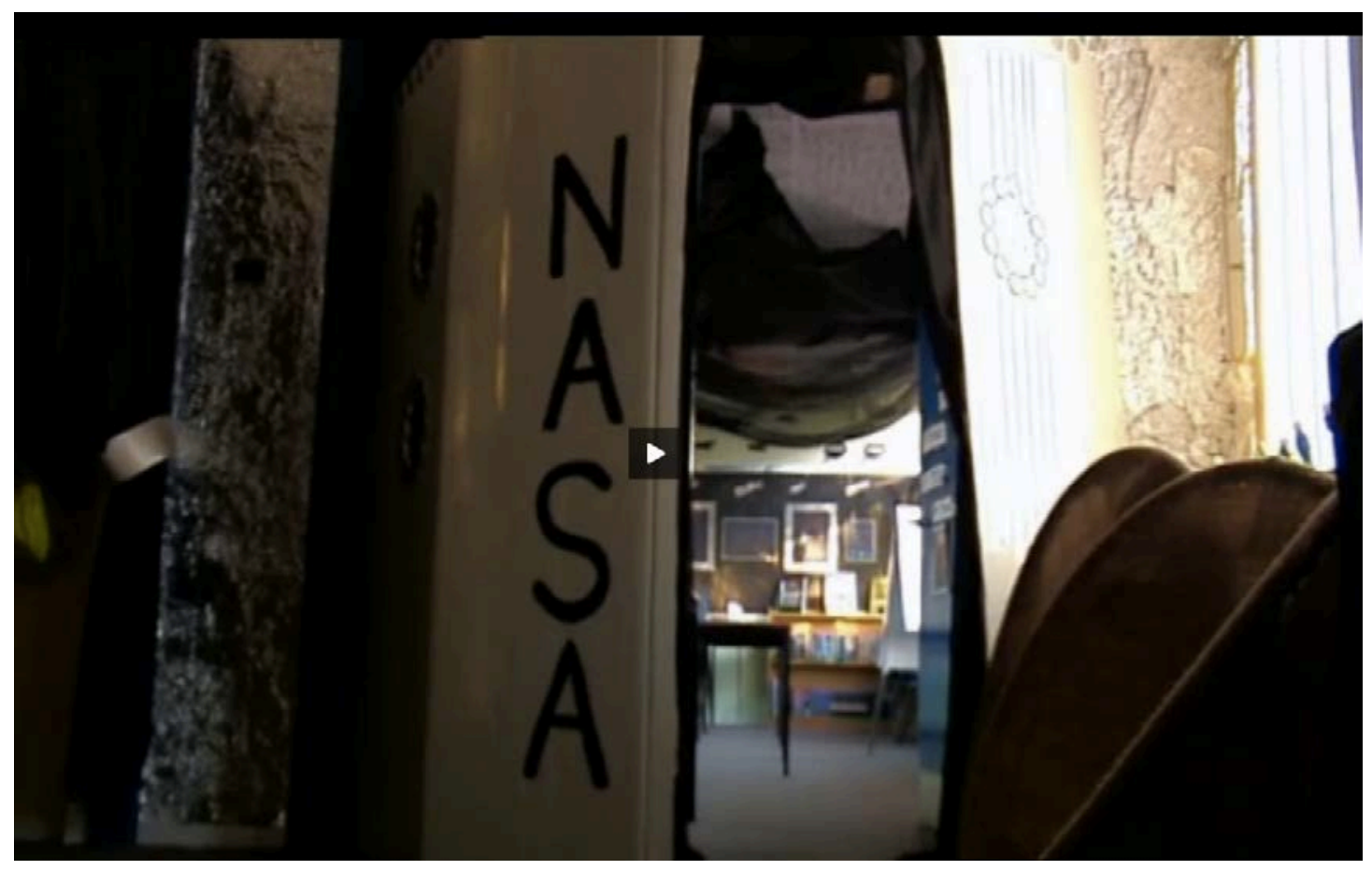

Figure 1 
Screen shot from 'Primary Topic Work - Customise Your Curriculum: Giant Leaps' showing a Year 5/6 classroom based on the theme 'Earth and Beyond'

(c) Teachers Media 2017

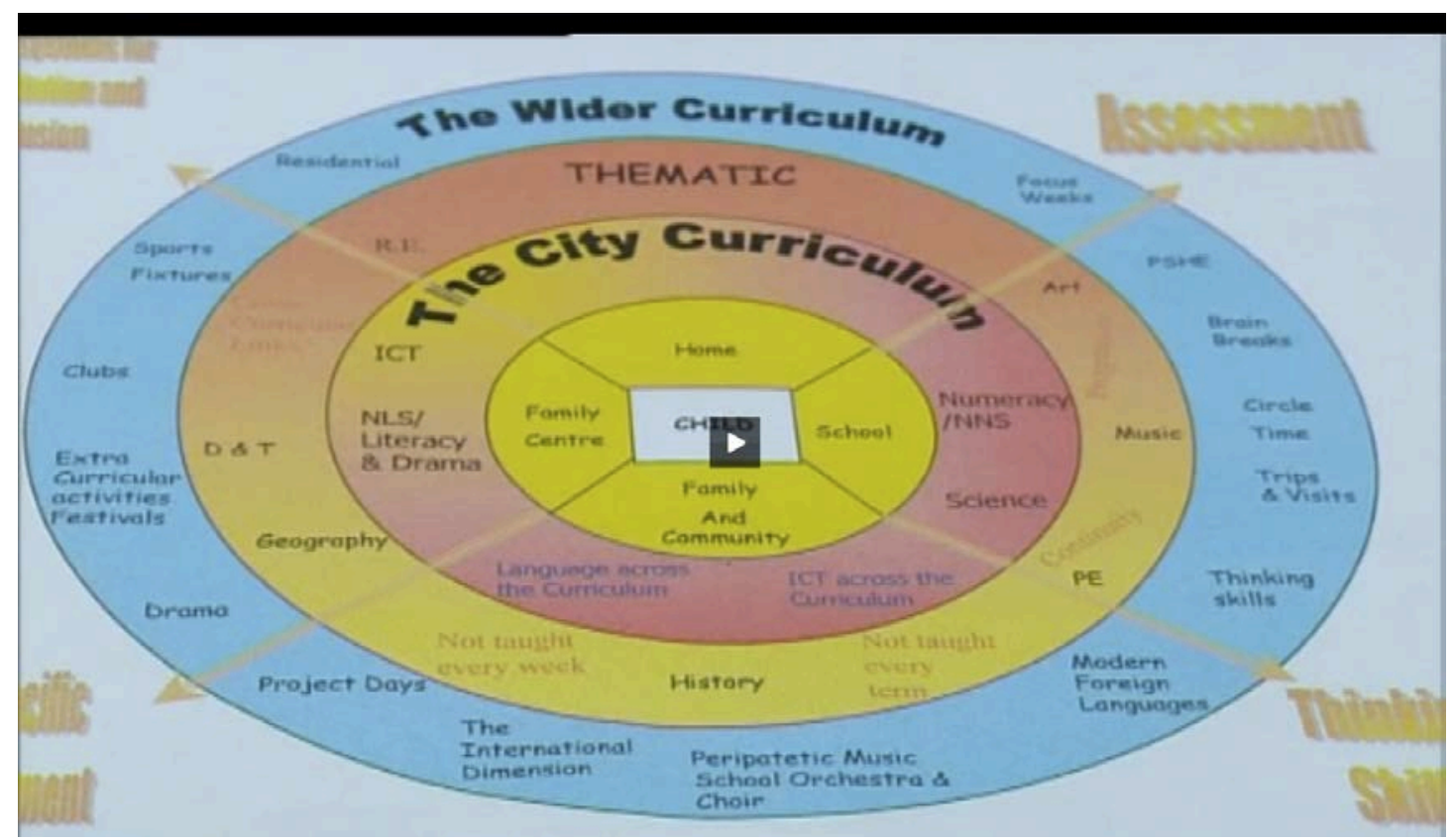

Figure 2

Screen shot from 'Primary Topic Work - Customise Your Curriculum: Giant Leaps' showing visual representation of how Kingsholm Primary School moved from a subject-based to a thematic curriculum

(C) Teachers Media 2017

\section{Conclusion}

Dewey's Democracy and Education still has relevance and resonance for the curriculum a hundered years after its first publication. His views on what constitutes democratic education are as pertinent now as they were in 1916. English education is currently debating how to facilitate identity, voice, nationhood and society into the curriculum. I have explored above how and whether Fundamental British Values supports this debate and the wider issue of a democratic school and curriculum. Dewey demands a lot of educationalists and pupils to create and maintain democratic ideals in the classroom but the returns are worthwhile for the child and society. Allied to this is Dewey's belief that education should not be 
compartmentalised into the 'academic' and the 'vocational'. This has been an Achilles' Heel for English education for at least two centuries. Dewey's theory of knowledge emphasises a deep relationship between theory and practice, concept and application. When the curriculum separates these elements, it creates a fundamental dislocation in a given curriculum with implications for the pupil, the school and society. Those with an interest in education should take a pause and reflect on Dewey's concerns for the curriculum - the centenary of Democracy and Education has been an ideal opportunity to do this.

\section{Word Count: 4,458 (excluding references)}

\section{References}

Alexander, R. (2008), Essays in Pedagogy, London: Routledge.

Department for Education, Promoting fundamental British values as part of SMSC in schools. Available at: https://www.gov.uk/government/uploads/system/uploads/attachment_data/file/38059 5/SMSC_Guidance_Maintained_Schools.pdf

Dewey, J. (1950 [1938), Experience and Education, New York: Macmillan.

Dewey, J. (2007 [1916]), Democracy and Education, Teddington: Echo Library.

Elton-Chalcraft, S., Lander, V., Revell, L., Warner, D. and Whitworth, L. (2017), To promote, or not to promote fundamental British values? Teachers' standards, diversity and teacher education, British Educational Research Journal, 43:1, pp. 2948.

Fielding, M. (2007), On the Necessity of Radical State Education: Democracy and the Common School, 41:4, pp. 539-557.

Teachers Media (2017), Primary Topic Work - Customise Your Curriculum: Giant Leaps [video] [online]. Available at: http://www.teachers-media.com/videos/primarytopic-work-customise-your-curriculum-giant-leaps\#video title bar (Accessed: 5 May 2017).

Dear Neil

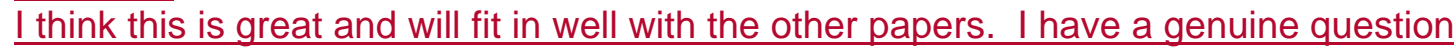
for you to consider - I wonder if primary educationalists might welcome you making 
the point early on that democratic values and practices are not just the reserve of secondary education but are highly relevant to primary aged children too?

If you could do a final check on spelling etc ref the track changes l've made and get back to me l'd be grateful - then perhaps give a final word count?

Many thanks for all your efforts on this - I really like the inclusion of the Primary school example..

Christine 